\title{
Civilization and Law: A Dark Optimism Based on the Precedent of Unprecedented Crises
}

\author{
John W. Head ${ }^{* *}$
}

\section{INTRODUCTION}

I would like to begin with a thesis and some expressions of thanks. First, the thesis - so you can decide right away if you should stay or just sneak quietly out the back door during one of the moments of thunderous applause that I expect to erupt during my presentation. The thesis of my remarks is this: Civilization has come under intense attack in the past 100 years. Over those same 100 years, law - and in particular a multilateral approach to law-has made an essential contribution to repelling those attacks and preserving civilization. The attacks on civilization continue today-and so a great challenge of our time, especially for lawyers and other informed citizens, is to decide how to harness the power of a

\footnotetext{
* This brief Article is a modified version of the inaugural lecture presented by Professor Head on November 11, 2010, at the University of Kansas to mark his designation as the Robert W. Wagstaff Distinguished Professor of Law. In keeping with common practice followed by the Kansas Law Review in publishing such inaugural lectures and consistent with the character of the lecture itself and the wishes of the author, this Article is structured more in the form of an essay than of a traditional law journal article, with less comprehensive citations to authority than might otherwise be provided. The focus of the lecture is general, drawing largely from Professor Head's own experience and familiarity with these well-documented events. The footnote citations are offered for readers who may have some interest in wishing to know a little more about where Professor Head drew his material.

** Professor of Law, University of Kansas, since 1990. Before beginning an academic career, Mr. Head practiced law in the Washington, D.C. office of Cleary, Gottlieb, Steen and Hamilton, and served as legal counsel for both the Asian Development Bank and the International Monetary Fund. He teaches in the areas of international law, international business, and comparative law, with a special emphasis on Chinese law. He has written widely on these subjects. His most recent book on Chinese law is China's Legal Soul: THE Modern CHINESE Legal IDENTITY IN Historical CONTEXT (2009). His recent books on international economic law include LOSING THE GLOBAL DEVELOPMENT WAR: A CONTEMPORARY CRITIQUE OF THE IMF, THE WORLD BANK, AND THE WTO (2008) and Global Business LaW: Principles and Practice of InTernational Commerce AND InVESTMENT (2007). He has taught in Austria, China, Hong Kong, Italy, Jordan, Mexico, Mongolia, Turkey, and the UK and has undertaken special assignments in numerous other countries. He is a Marshall Scholar and has twice been awarded Fulbright Lecturing Fellowships-most recently in 2009 at the University of Trento.
} 
multilateral approach to law in order to meet these contemporary attacks on civilization.

Now let me turn to some expressions of thanks. I am grateful and honored to have been selected as the third holder of the Robert W. Wagstaff Distinguished Professorship, and I wish to thank the Wagstaff family for the generosity that made this possible. I also wish to thank my own family. The many years of support I have received from themincluding my father, who died just last year at the age of ninety-eighthave created a debt that can never be repaid, something that in Tagalog (the dialect used around Manila, where my wife and I once lived) would be called utang na loob. ${ }^{1}$ Moreover, I want to add a special thanks to my colleagues on the KU Law faculty. Ever since Lucia and I arrived here in Lawrence twenty years ago, we have felt at home in a community of scholars and friends who have proven much more intellectually engaging than I ever imagined and have shown me much more patience than I ever deserved.

I have chosen a rather expansive topic for my remarks today: "Civilization and Law." As with most books or articles, of course, we would expect the title to go on, first with a colon and then with a subtitle-something like "Civilization and Law: The Manifestation of Existential Anxiety in Episode 16 of The Simpsons." That is not the subtitle of my talk today, but I know you're wondering just what it is; you're wondering what comes after the colon. From a physiological perspective, of course, we could ask Dr. Phil Hoffman here in Lawrence; he certainly knows what comes after the colon. But what comes after my colon-that is, the colon in my title-is this: "A Dark Optimism Based on the Precedent of Unprecedented Crises.”

What can this possibly mean? Let me try to explain it by restating my thesis and then by examining each of the main elements of the entire title-beginning with the first word, "Civilization," and then "Law," and then "the Precedent of Unprecedented Crises," and lastly my "Dark Optimism.”

Again, my overall thesis is that civilization has come under intense attack in the past 100 years; and that over those same 100 years, law has made an essential contribution to repelling those attacks and preserving

1. Utang na loob is no ordinary debt. It is a characteristically strong sense of gratefulness taken with extreme seriousness by Filipinos. Utang na loob is, in many ways, a debt incurred by the inner being of a person, a soul debt, which persists and endures, even after the original debt has been paid.

Francis Dancel, Utang Na Loob [Debt of Goodwill]: A Philosophical Analysis, in FILIPINO Cultural Traits: Claro R. Ceniza Lectures 113 (Rolando M. Gripaldo ed., 2005). 
civilization. If civilization is like the Star Ship Enterprise, in Star Trek, then law is like the "plasma shield" that Captain James Kirk could activate to protect the ship against sure destruction-not unlike a protective shield that scientists are working on today. ${ }^{2}$ One of the great challenges in this century will be to determine how this protective action can be taken once again in the face of what I regard as extraordinarily violent attacks today on civilization.

\section{CIVILIZATION}

First, what do I mean by civilization and how it has been attacked? When Lucia and I were newly married and living in Georgetown, just west of downtown Washington, D.C., we found that we could go to the library of Georgetown University and watch the various episodes of Kenneth Clark's series titled Civilisation. ${ }^{3}$ So we did that.

Most of you probably remember Kenneth Clark's work. If so, you may recall that the first episode in Clark's film series is titled "The Skin of Our Teeth." ${ }^{4}$ He explains that civilization-more precisely, the civilization of the ancient world of Greece and Rome-just barely survived the centuries between the fall of Rome in the fifth century and the return of light to Europe in the late eleventh century. We only made it through that period of darkness, Clark asserts, by the skin of our teeth. ${ }^{5}$

In making this assertion, Clark dances around a definition of civilization. Here is one thing he says about civilization:

2. According to the European Incoherent Scatter Scientific Association, a team of scientists has been working on an artificial magnetosphere that could be generated around manned space craft en route to the Moon or Mars to protect the occupants from the potentially lethal radiation in space from the Sun. See European Incoherent Scatter Scientific Ass'n, Shields for the Starship Enterprise: A Reality?, http://www.thelivingmoon.com/45jack_files/03files/EISCAT_Artificial_Magnetic_ Shield.html. A superconducting ring on board such a space craft could produce a magnetic field, or mini-magnetosphere, similar to the Earth's, which would create a deflector or plasma shield similar to that featured in the Star Trek series. Id.

3. Civilisation (BBC television broadcast Feb. 23-May 18, 1969). Accompanying the film series was a book, KenNETH CLARK, CiVILISATION: A PERSONAL VIEW (1969).

4. Civilisation: The Skin of Our Teeth (BBC television broadcast Feb. 23, 1969).

5. Id. The students who take my Comparative Law course know something about this. They know how remarkable a coincidence it was that Justinian's Digest - part of the great compilation of classical Roman law issued by Justinian in Constantinople around $533 \mathrm{AD}$ - was rediscovered in northern Italy at just the right moment in the late eleventh century to serve as the body of legal doctrine that eventually became the centerpiece of European civil law, lasting even to this day. See John W. Head, Great Legal Traditions: Civil LaW, Common LaW, and Chinese LAW iN HISTORICAL AND OPERATIONAL PERSPECTIVE ch. 2, § II.A.1 (forthcoming 2011). 
[A]t certain epochs man has felt conscious of something about himself-body and spirit—which was outside the day-to-day struggle for existence and the night-to-night struggle with fear; and he has felt the need to develop these qualities of thought and feeling so that they might approach as nearly as possible to an ideal of perfection-reason, justice, physical beauty, all of them in equilibrium.

Now that seems pretty abstract, especially for me as a lawyer or Keith Meyer as a specialist in agricultural and commercial law or Craig Huneke as a mathematician or Prakash Shenoy as a specialist in artificial intelligence. But Kenneth Clark goes on to say that civilization is a spirit and a strength that comes from confidence- "confidence [he says] in the society in which one lives, belief in its philosophy, belief in its laws, and confidence in one's own mental powers." " He points-literally, in the filmstrip, he points - to the Pont du Gard, in southern France, and says this:

The way in which the stones of the Pont du Gard are laid is not only a triumph of technical skill, but shows a vigorous belief in law and discipline. Vigour, energy, vitality: all the great civilisations-or civilising epochs-have had a weight of energy behind them.

Merging these ideas into a single rough-and-ready definition, I would say that "civilization" is the sustainable, self-conscious human energy and vitality that pushes back the immediate burdens of (what Kenneth Clark calls) the day-to-day struggle for existence and the nightto-night struggle with fear, and that replaces these burdens with a spirit of building, of confidence, of collective commitment to other members of the society, and an optimism in one's shared future within that society. ${ }^{9}$

6. ClARK, supra note 3 , at 3 .

7. Id. at 4.

8. Id. He goes on to say this: "People sometimes think that civilisation consists in fine sensibilities and good conversation and all that. These can be among the agreeable results of civilisation, but they are not what make a civilisation, and a society can have these amenities and yet be dead and rigid." Id.

9. As an aside, I would note that there is a different way of looking at the concept of “civilization.” In traditional China, which I know just enough about to be dangerous, the concept of “civilization” carried a meaning that looks rather different from our Western concept-although maybe not so much, on reflection. Here is how Derk Bodde, one of the giants among Western scholars of Chinese law, has explained the concept of "civilization" (or perhaps the concept of "culture") in traditional China:

Our word "civilization” goes back to a Latin root having to do with "citizen” and "city."

The Chinese counterpart, actually a binom, wen hua, literally means "the transforming

[i.e., civilizing] influence of writing." In other words, for us [in the West] the essence of 
It is not an exaggeration, I believe, to say that civilization-using my definition or nearly any definition-came under fierce attack at least twice in the twentieth century and that it has been under some form of siege for most of the last 100 years. If we think in terms of a global civilization (as I think we should), we might say that these attributes that I have mentioned-confidence, energy, building, and social consciousness - were at real risk of being killed or seriously injured by World War I, and then again by World War II, and that a cascade of destructive developments that followed those catastrophes has left civilization in a weakened state.

\section{LAW}

Law, so far, has come to the rescue. Now that might strike you as an odd thing to say-Law, so far, has come to the rescue? For many people, law is an intrusive and disruptive and even destructive institution. I believe a lot of people, including people in this country, regard law as an impediment to progress, and perhaps even an impediment to justice.

At first glance this assertion would seem counterintuitive, that law could be an impediment to justice, but consider the famous exchange between William Roper and Thomas More in the film (and play) A Man for All Seasons. ${ }^{10}$ The setting is this: A young man comes to Thomas More's house to ask for a job. Thomas More is the Lord Chancellor of England in the 1530s under Henry VIII. Thomas More knows this young man to be a spy for some members of Henry VIII's court-and that in fact this young man himself is very likely to conspire against Thomas More, who has refused to help Henry VIII in his struggles against the Pope. When the young man leaves the room, Thomas More's son-inlaw, William Roper, tells his father-in-law that he should arrest the

civilization [or "culture"] is urbanization [or I might say "the joys and challenges of living in a concentrated society"]; for the Chinese it is [an energy and consciousness reflected in] the art of writing.

Derk Bodde, Introduction to the History of China, in BRAdLEy SMITH \& WAN-Go WeNG, CHINA: A HISTORY IN ART 10 (1973) (first alteration in original), quoted and explained in JOHN W. HEAD \& YANPING WANG, LAW CODES IN DYNASTIC CHINA: A SYNOPSIS OF CHINESE LEgAL HISTORY IN THE THIRTY CENTURIES FROM ZHOU TO QING 83 (2005). As an academic, I find myself attracted to that emphasis on writing - or maybe in contemporary society we could say not just writing but "reflective expression" more generally. Through the practice of expressing and exchanging our observations of the world and our place in it, we make it possible to survive and maybe prosper as a global society. But as a practical matter, we cannot have free expression and exchange of ideas without the kind of energy and vitality and collective commitment to other members of the society that Kenneth Clark's definition of "civilisation" involves.

10. A MAN FOR All SEASONS (Highland Films 1967). 
young man because he has violated God's law, and that the young man represents the Devil himself - and the Devil should not be able to hide behind the laws.

Here is the exchange:

[Roper:] So, ... you give the Devil the benefit of law!

[Sir Thomas More:] Yes! What would you do? Cut a great road through the law to get after the Devil?

[Roper:] Yes, I’d cut down every law in England to do that!

[Sir Thomas More:] Oh? And when the last law was down, and the Devil turned 'round on you, where would you hide, Roper, the laws all being flat? This country is planted thick with laws, from coast to coast, Man's laws, not God's! And if you cut them down-and you're just the man to do it-do you really think you could stand upright in the winds that would blow then? Yes, I'd give the Devil benefit of law, for my own safety's sake! ${ }^{11}$

I agree with that sentiment - that is, in times of crisis, law is our best defense, a bulwark against evil. Law itself can be evil, to be sure-or can be made to serve evil purposes, as we have seen for example in Hitler's Germany. And even if law is virtuous rather than evil, law can never be a sufficient defense; but it is, I believe, a necessary defense.

And it was a defense, more than once, during some very dark days of the twentieth century. Let me offer these illustrations, beginning with World War I.

On the eleventh hour of the eleventh day of the eleventh month of 1918 - exactly nine-two years and twelve hours ago (taking into account the time-zone differences) - a cease-fire went into effect, bringing a close to the carnage of the war. At the time of the cease-fire that day, my mother's father was in France with the U.S. forces; Lucia's mother's father was also in France that day with the U.S. forces. Both returned home, but Lucia's grandfather had shrapnel in his legs that affected him for the rest of his life. Millions of young men and women, of course, were killed; millions more were maimed. European economies were ruined. Political institutions were in chaos.

One of the responses to this chaos involved law. And now it is time for me to explain what I mean by "law" in this context. In general, I regard law as a combination of three elements: rules, institutions, and a 
collective acceptance of those rules and institutions. The last of thesecollective acceptance-is what H.L.A. Hart calls the "internal aspect" or the internal attitude or the internal acceptance of law. ${ }^{12}$ Hart, writing in the 1950s, explains that the positivist John Austin, who wrote in the early 1800s, misconceptualized law when he insisted that there can be no law without centralized orders issued by a sovereign and backed by force. ${ }^{13}$ Hart says that force can certainly compel compliance, but that force is not what lies at the center of law. ${ }^{14}$ What lies at the center of law is a shared acceptance of the rules - so that when we follow the rules, Hart says, we do so not primarily because we are being forced to do so but instead because we regard them as "our" rules, because we are recognizing our shared values in a civilized society. ${ }^{15}$

And so it is for those reasons that I include three elements in my definition of law: rules, institutions, and a collective acceptance of those rules and institutions.

In days just following World War I, what kind of "law response" was attempted, using this definition of "law"? As you know, one of Woodrow Wilson's Fourteen Points called for the creation of a league of nations. ${ }^{16}$ That was done. The treaty that created the League of Nations included provisions that placed legal restrictions on the use of force by member countries. ${ }^{17}$ Specifically, a three-month "cooling-off” period was imposed, along with a requirement that disputes between countries must be handled through arbitration, at least during that cooling-off period. ${ }^{18}$ And a special Council was created within the League of Nations to handle such disputes in a collective fashion.

Another "law response" to World War I was the creation of a court, the Permanent Court of International Justice, that would help facilitate peaceful resolution of international disputes. ${ }^{19}$ A fourth response in law to World War I was the International Labour Organization, created on grounds that one underlying cause of the Great War was economic in

\footnotetext{
12. H.L.A. HART, THE CONCEPT OF LAW 55, 86-88 (1961).

13. Id. at $18-25$.

14. Id.

15. Id. at $99-107$.

16. President Woodrow Wilson, The Fourteen Points Address (Jan. 8, 1918), available at http://usinfo.org/docs/democracy/51.htm.

17. League of Nations Covenant art. 12.

18. Id.

19. The Court: History, THE INT'L CT. JUST., http://www.icj-cij.org/court/index.php?p1=1 \&p2=1\&PHPSESSID=953fa244902cca6c690ebd547e0e50ae\%Permanent (last visited Feb. 13, 2011).
} 
character, flowing out of the huge disruptions brought about by the Industrial Revolution. ${ }^{20}$

Now everyone knows the League of Nations failed. Or did it? When a baby takes its first steps, it inevitably falls down. Even the smartest little tyke, on first trying to walk, will take no more than three or four steps before ending up on the floor. And then what will happen? Will the baby's parents suddenly scowl with derision and call the baby a failure when the baby falls down? No; the baby's first steps are a huge success, notwithstanding the fact that just a moment later, the baby falls down.

Of course, my thesis does not turn on whether the League of Nations was a success or a failure. My point is this: When crisis hit, when civilization was under violent attack, law was one of the instruments (not the only one, of course) that the leaders of the day employed to respond to that attack. There were rules (for example, the three-month coolingoff period), institutions (for example, the League of Nations, the Permanent Court of International Justice, the International Labour Organization), and a collective acceptance of those rules and institutions.

Some of those rules and institutions did not survive long. Their demise resulted not, I think, from defects or absurdities in the rules and institutions themselves but from an evaporation of the third element- the collective acceptance. But those rules and institutions from 1920 are widely regarded as the foundations for further, more ambitious rules and institutions that were put in place a generation later when another great crisis attacked civilization.

\section{THE PRECEDENT OF UNPRECEDENTED CRISES}

I treat World War I as an unprecedented crisis. I treat World War II as another unprecedented crisis. Yes, of course, it was another war. But the scale of that later war, its geographic reach, its imaginative machinery for destruction, its breathtaking revelations of human cruelty - all these, I believe, put World War II in a class by itself, unprecedented save in this one respect: it was preceded by a similarly unprecedented crisis. This is why I have used a rather curious phrase in the subtitle to my remarks today- "the precedent of unprecedented crises.” 
If the crisis of World War I sparked a burst of law-based responsesrules, institutions, attitudes-then the crisis that was World War II unleashed a virtual eruption of law-based responses. A list of them would include such things as the United Nations (and the charter that governs it), the International Court of Justice (and the statute that governs it), the International Monetary Fund, the World Bank, the General Agreement on Tariffs and Trade (GATT), the Universal Declaration of Human Rights, the Genocide Convention, the Geneva Conventions, and the Nuremberg Charter. We do not have time to examine all of these, so let me highlight just three that I am most familiar with: the global economic organizations, most prominently the World Bank, the International Monetary Fund, and the GATT (which more recently has expanded into the World Trade Organization).

The statesmen of the day created these global economic institutions as counter-attacks to the economic chaos that had occurred in the years between the wars. Some of that economic chaos broke out, of course, in Germany. A banknote issued in that country in 1923 with a face value of fifty million deutschmarks was worth about one U.S. dollar upon its issuance. Had it been issued nine years earlier, in 1914, it would have been worth about twelve million U.S. dollars. A few weeks after its issuance, it was almost worthless. ${ }^{21}$ Another way to look at the same phenomenon is to measure the rate of inflation. According to one source, Germany's inflation rate in October 1923 reached 20.9\% per day, which is over 20,000\% per month. ${ }^{22}$ Even a quick Google search will produce numerous illustrations of Germany's runaway inflation in the inter-war period with images of people using banknotes as wallpaper and of children playing with bundles of money ${ }^{23}$ — such was the economic chaos in Germany in those days. But the chaos extended widely-including of course in the United States. My father's father was president of a bank in our little home town in northeast Missouri. It closed during the banking crisis of the 1930s; it never reopened.

Convinced that the world had descended into World War II partly from economic chaos, the architects of a new world order following that

21. Mark (money), WIKIPEDIA, http://en.wikipedia.org/wiki/Mark_(money) (last visited Jan. 28, 2011); see also John P. Dawson, Effects of Inflation on Private Contracts: Germany, 1914-1924, 33 MiCH. L. REV. 171, 174 n.11 (1934).

22. Steve H. Hanke, R.I.P. Zimbabwe Dollar, CATO InstiTUTE (Feb. 5, 2009), http://www.cato.org/zimbabwe; see also Hyperinflation, WIKIPEDIA, http://en.wikipedia.org/wiki/ Hyperinflation (last visited Jan. 28, 2011) (listing various other sources and details).

23. GOOGLE, http://www.google.com (search "Germany inflation children playing wallpaper money”). 
war took bold steps. They agreed to remove the sovereign right of a country to change its own currency values willy-nilly; they agreed to remove the sovereign right of a country to change its tariff rates willynilly; they agreed to establish a bank that would finance the rebuilding of Europe and the economic development of newly independent countries around the world. These initiatives - taken in the context of the IMF, the GATT, and the World Bank, respectively - contributed to what I call an eruption of multilateralism. ${ }^{24}$

This eruption of multilateralism extended far beyond economics, of course. The architects of a new world order also agreed through various other treaty commitments to remove the sovereign right of a country to use aggressive military force against another country. They prosecuted Nazi War leaders at Nuremberg, to make them personally criminally liable for acts they carried out as government officials-the first time such a prosecution had ever even been conceived. They outlawed genocide. They wrote charters for global human rights protection. To implement these novel rules, they created new institutions and breathed life - that is, legal personality - into them. And they did all of this—all of the new rules and all of the new institutions that I have just mentioned-within the space of five years, between 1944 and 1949.

How was that possible? It was possible because of the third ingredient of law, as I have defined it. Remember that in my definition, law consists of rules, institutions, and a collective acceptance of those rules and institutions. At least as I see it, the spirit of the time was one of collective acceptance of the need for bold steps. To use Hart's phrase, there was an "internal aspect" to the new rules and institutions, an attitude that was fueled by the common realization that civilization had come under harsh attack and that such an unprecedented crisis required unprecedented responses_-particularly law-based responses.

Perhaps a more upbeat way to say this is that the crisis had illuminated a set of shared values and that this illumination made bold steps not only possible but attractive. Some of you might go to Plymouth Congregational Church here in Lawrence. If I went there more often, I guess I'd know whether or not some of you go there. Every week, the congregation at Plymouth Church recites collectively the Plymouth Covenant, printed on the front of the bulletin. In doing so, they identify several goals they have, by common consent, decided to work toward

24. For more details on these multilateral economic initiatives, see JOHN W. HEAD, LOSING THE GLOBAL DEVELOPMENT WAR: A CONTEMPORARY CRITIQUE OF THE IMF, THE WORLD BANK, AND THE WTO 91-166 (2008). 
collectively. Of all those goals, the one that appeals to me the most is this one: "the realization of our shared humanity.,"25

I like to view the eruption of multilateralism that occurred between 1944 and 1949 not only as a defensive response to the unprecedented crisis of the day but also as a positive response to a new world view emerging from that crisis-in other words, a "realization of our shared humanity," with an optimism that maybe collective action could bring real improvements in international economic relations, political relations, human rights protections, and other areas.

It's enough to make you want to sing a song of sentimental celebration-isn't it? How about this:

Those were the days, my friend; we made a great UN.

The IMF and the World Bank were the best!

No, it is obvious to anyone that the rules and institutions that were put in place in that eruption of multilateralism were not so great; they had many flaws and fault lines. For the past twenty years, I have been a persistent critic of the global economic institutions that date from the 1940s. I believe they need fundamental change, despite several rounds of reform that they have already passed through. But I also believe that some form of global economic collaborative regime-that is, a set of robust rules and institutions-is a necessity for now and for the future.

The same point applies more generally, beyond economics. Having studied now for about three decades the various global institutions and the many efforts that have been made to protect the environment and beat back government corruption, having witnessed poverty all over the world, and having been inundated with accounts of war and genocide, I find the landscape of international relations absolutely littered with reasons for despair. And yet, I also see a need, more urgent every year, for some form of collective rules and institutions built upon the rather timid rules and flawed institutions that we have today, as vestiges of that eruption of multilateralism that occurred sixty years ago.

\section{A DARK OPTIMISM}

Now I want to introduce my "dark optimism." (You probably thought I had already made things pretty dark.) In thinking about civilization and law, I harbor a dark optimism that I would summarize in

25. For the full text of the Plymouth Covenant, see Plymouth Covenant, PLymouth CONGREGATIONAL CHURCH, http://www.plymouthlawrence.com/who/covenant/ (last visited Feb. 13, 2011). 
this way: Although our current global society faces terrible problemsproblems that require global solutions-we will find ourselves powerless to address those problems effectively until they escalate into a crisis equivalent in scale to the crises of World War I and World War II; but when that crisis comes, whatever specific form it takes, we will as a global society probably find some temporary law-based responses that will help us muddle through that crisis, saving civilization by the skin of our teeth-because we have done so before.

\section{A. A Parade of Problems}

In the few minutes that remain, let me try to "unpack" that synopsis, phrase by phrase. I begin with the opening proposition-that our global society faces terrible problems. Four categories of problems should suffice to support this proposition. All of these categories of problems exist at the global level, and they all are unprecedented either in content or in scale. ${ }^{26}$

\section{Galloping Population}

Again, a simple Google search will yield countless graphs and figures $^{27}$ that highlight the dramatic and unprecedented increases in human population that have occurred over various time periods-with a drastic jump in just the last one hundred years. When my mother was eight years old - in 1928 - the Earth held two billion people. When I was eight years old-in 1961 - the Earth held three billion people. When my daughter Jessica was only one year old —in 1987-that figure had jumped from three to five billion. In just two or three years from now it will reach seven billion.

\section{Global Warming}

Average surface temperatures of the Earth are rising dramatically, as greenhouse gas emissions proliferate. Indeed, graphs depicting global

26. For a more extended discussion of these and other global problems, see HEAD, supra note 24 , at 36-41.

27. GOOGLE, http://www.google.com (search "world population growth chart"); see also Population Growth over Human History, The Global Change Program AT University of MiCHIGAN (Jan. 4, 2006), http://www.globalchange.umich.edu/globalchange2/current/lectures/ human_pop/human_pop.html. 
warming $^{28}$ and increases in atmospheric $\mathrm{CO}_{2}$ levels ${ }^{29}$ resemble those depicting population growth.

\section{Environmental Degradation}

The world's biological diversity declines every year. We are losing the richness of variety in plant and animal species. ${ }^{30}$ Vast areas of natural ground cover and habitat—such as the native grasslands that we love here in Kansas-have largely disappeared. Deserts have expanded. Many forest areas face extensive degradation.

\section{Economic Distress}

According to some estimates, over eighty percent of the world's population has to survive on less than ten dollars day, ${ }^{31}$ and between forty percent and fifty percent of the world's population has less than two dollars a day - that being below the commonly-accepted global poverty level. $^{32}$ In a great many countries around the world, at least thirty percent of the population lives below the poverty line. ${ }^{33}$

28. See, e.g., Nick Hopwood \& Jordan Cohen, Greenhouse Gases and Society, http://www.umich.edu/ gs265/society/greenhouse.htm (last visited Feb. 13, 2011) (depicting rising temperatures from the 1860 s to today).

29. See, e.g., Global Atmospheric Concentration of $\mathrm{CO}_{2}$, UNEP/GRID-ARENDAL, http://www.grida.no/publications/vg/climate/page/3062.aspx (last visited Feb. 13, 2011). For more on details and charts on global warming, see "Little Green Data Book 2007": Carbon Dioxide Emissions on the Rise, Warns World Bank Publication, THE WORLD BANK (May 8, 2007), http://web.worldbank.org/WBSITE/EXTERNAL/NEWS/0,,contentMDK:21328109 pagePK:34370 $\sim$ piPK:34424 theSitePK:4607,00.html; Hopwood \& Cohen, supra note 28.

30. Species Extinction and Human Population, WhOLE Sys. FounD., http://www.wholesystems.org/extinctions.html (last visited Feb. 13, 2011).

31. Anup Shah, Poverty Facts and Stats, GLOBAL IssuEs, http://www.globalissues.org/ article/26/poverty-facts-and-stats (last modified Sept. 20, 2010) (showing the percentage of the global population at different poverty levels in 2005).

32. The World Bank, on whose figures many other sources rely, estimates that in 2005 the proportion of global population living on less than two dollars per day was about forty seven percent. See Poverty: At a Glance, THE WORLD BANK, http://web.worldbank.org/ WBSITE/EXTERNAL/TOPICS/EXTPOVERTY/0,,contentMDK:20040961 isCURL:Y menuPK:3 73757 pagePK:148956 piPK:216618 theSitePK:336992,00.html (last updated September 2010); see also More than Half the World Lives on Less than \$2 a Day, POPULATION REFERENCE BUREAU, http://www.prb.org/Journalists/PressReleases/2005/MoreThanHalftheWorldLivesonLessThan2aDay August2005.aspx (last visited Feb. 13, 2011).

33. CIA, THE WORLD FACTBOOK (2009), available at https://www.cia.gov/library/publications/ the-world-factbook/fields/2046.html. 


\section{B. The Search for Global Solutions}

Let me turn to the second proposition in my "dark optimism" as summarized above-that the global problems we face require global solutions. I will not offer any support for this proposition-it seems so self-evident to me, and I hope to you. What is not self-evident, of course, is precisely what the legal and institutional framework should be for those global solutions. Should there be some new version of the United Nations? Or should we abandon that approach, which rests on the foundation of a nation-state system that was created in the seventeenth century and now seems outmoded? Should we have a Concert of Great Powers of the sort that the crowned heads of Europe created around 1815 in response to the Napoleonic Wars and the French Revolution? Or does that strike us as antidemocratic, for the same reasons that the unofficial power of the G-7 has recently shifted to the G20 ? Should non-state actors-for example, NGOs and multinational corporations - have international legal personality and therefore carry a full portfolio of legal rights and duties at the global level? These are the sorts of questions I have been engaged in-along of course with a great many other lawyers and academics. My point now is not to address them but merely to assert this second proposition - that because global society faces problems that encompass all humanity, global solutions will be required.

\section{A Really Big Show?}

Now for the third proposition in my "dark optimism" as summarized above- that we will find ourselves powerless to address those problems effectively until they escalate into another unprecedented crisis. I participated in October 2009 in a conference in Sacramento regarding the global financial crisis. After I made my presentation there, the moderator started calling me "Dr. Doom" because I said the crisis had not been serious enough to force any fundamental changes in legal rules and institutions central to the international financial system. And, in fact, over the past year or so, most proposals for such change have been diluted or discarded.

I think it takes what the early television variety-show host Ed Sullivan would have called "a really big show"-or what I would call "a really big crisis" - to draw out the sense of urgency, and of fear for the future, necessary to create fundamental change of the magnitude that we saw at the close of World War I and World War II. After all, law is a fundamentally conservative, slow-moving institution. I think it is not 
nimble enough to keep up with many of the quickly changing circumstances in society.

You might disagree. You might point out that we have had big problems before-less serious than a world war but just as profound as the problems I mentioned earlier: population growth, pollution, poverty. Haven't we shown enough resourcefulness to have somehow muddled our way through the worst of them? Take population growth. Thomas Robert Malthus, writing at the end of the eighteenth century, painted a picture of a world whose population would soon expand so much as to bring "premature death," "epidemics, pestilence, and plague," and ultimately a "gigantic inevitable famine."

But this has not happened yet, partly because of the efforts of Norman Borlaug. He is considered the father of the "Green Revolution" by which yields of food-crops increased dramatically. ${ }^{35}$ Maybe the next hero in this regard-again not a lawyer but a scientist and manager-will be Wes Jackson, who founded the Land Institute near Salina three decades ago. ${ }^{36}$ Perhaps his team of scientists there will continue to work some genetic wizardry that will yield what I call HerPerSeeProPol-a herbaceous perennial seed-producing polyculture, which will transform the destructive way we have engaged in agriculture for the past several thousand years.

And what about "peak oil"? Haven't we heard warnings for decades that the world is about to run out of oil, and yet don't we continue to find new sources of oil, and don't we continue to develop alternative sources of power-such as the technology that runs my son's Toyota Prius?

Expressed differently: Haven't we been at the edge of the Precipice of Peril before, and then taken a Soaring Ascent of Survival rather than the Dismal Descent of Death? Yes, that's true. We have, so far, muddled through. The world still exists, and we still drive our cars on

34. Thomas Malthus, An Essay on The Principle of Population 44 (Elec. Scholarly Publ'g Project 1998), available at http://www.esp.org/books/malthus/population/malthus.pdf. He claimed:

The power of population is so superior to the power of the earth to produce subsistence

for man, that premature death must in some shape or other visit the human race....

Epidemics, pestilence, and plague, [will] advance in terrific array, and sweep off their thousands and tens of thousands. Should [this process of reducing the population to match the food supply] be incomplete, gigantic inevitable famine stalks in the rear, and Id. with one mighty blow levels the population with the food of the world.

35. Kathryn McConnell, Norman Borlaug, “Father of the Green Revolution," Dies at Age 95, AMERICA.GOV (Sep. 15, 2009), http://www.america.gov/st/develop-english/2009/September/ 20090915245901akllennoccm0.5653955.html.

36. See THE LAND INSTITUTE, http://www.landinstitute.org/ (last visited Jan. 28, 2011). 
halfway decent roads, and there is still food on the shelves at Dillon's and Checkers and Hy-Vee and the Merc. But I draw little comfort from these facts because the pace of urgency is so much faster now.

\section{The Skin of Our Teeth?}

In short, given these considerations, I think it takes a crisis. But this is where I turn to the last proposition in my "dark optimism" summarized above: When the new unprecedented crisis comes, whatever specific form it takes, we will as a global society probably find some temporary law-based responses that will help us muddle through that crisis, saving civilization by the skin of our teeth... because we have done so before-or, more precisely, because earlier generations have done so before. I have tried to illustrate how in the unprecedented crises of World War I and World War II, law-based responses came to the rescue-in addition, of course, to political will and military superiority and other responses beyond the law-based responses that I have focused on.

So even though I have in essence said that law-that is, rules, institutions, and an attitude of collective acceptance-probably cannot keep up with global problems on an ongoing basis, I believe that law probably can catch up, in a time of unprecedented crisis, to help save civilization. It has done so in the past.

\section{CONCLUDING THOUGHTS}

Let me close with a final observation-it serves as a punch line, at least for me. Even if my "dark optimism" is warranted-that is, even if the twentieth century tells us we can probably save civilization by the skin of our teeth by doing dramatic repair work just at those times of unprecedented crisis-it does not mean that we can wait for the moment of crisis in order to dream up the necessary solutions. In particular, I believe that from a legal perspective we must make preparations now, by struggling to design the new rules, institutions, and attitudes that will allow us to meet the crisis when it comes.

After all, the law-based responses to the crises of the twentieth century were not created on the spot. A hundred and thirty years before the Versailles Peace Conference, which created the League of Nations and the Permanent Court of International Justice, Jeremy Bentham had 
proposed similar institutions, and in the 1840s, William Ladd created a more detailed blueprint for them. ${ }^{37}$ And in the years preceding the Bretton Woods Conference, which created the World Bank and the IMF, John Maynard Keynes and Harry Dexter White and many others were proposing global economic rules and institutions. Indeed all of the components of the "eruption of multilateralism" that occurred in the 1940s - the Genocide Convention, the Universal Declaration of Human Rights, the Geneva Conventions, the GATT - all of these were preceded by a collective, slow-motion conversation, basically about civilization and how to save it once the storms had passed. One thing I have tried to do in my career, particularly over the past twenty years, is to participate in that conversation about civilization and law.

37. MARK WESTON JANis, InTERNATIONAL LAW 210-11 (5th ed. 2008). 